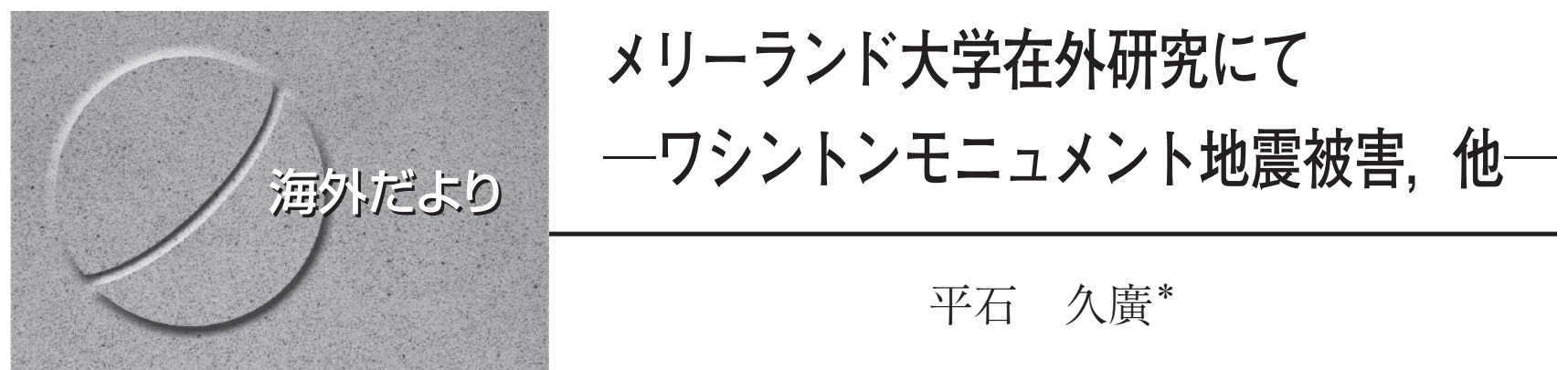

1.はじめに

筆者は本年 4 月中旬より 9 月初旬まで米国メリーラン ド大学にて在外研究の機会を得た。以下ではメリーラン ド大学の概要や我が国の耐震関係者にはあまり馴染みが ないと思われる東海岸の耐震に関する情報などを記した。

\section{University of Maryland}

メリーランド大学は, ワシントン DC 北東のメリーラ ンド州カレッジパークを本拠とする州立大学で 1856 年 に創立された。現在は計 14 学部 (college と school) か らなる州立総合大学で，アメリカ連邦政府や各種政府関 係機関に近いという立地もあり，豊富な外部研究資金を 活かした研究を行っている。

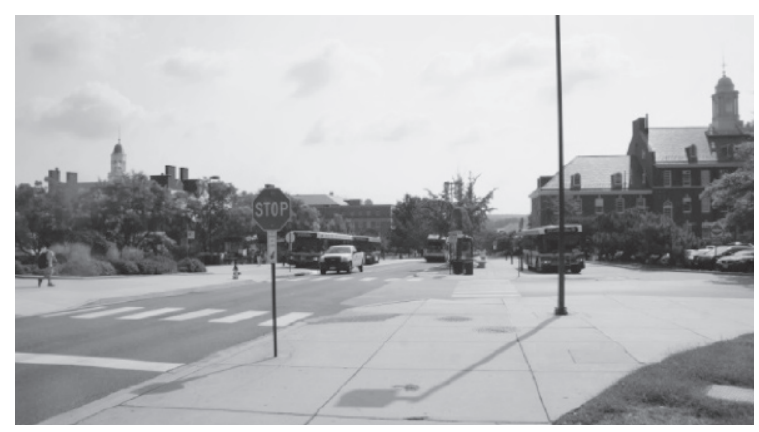

写真-1 University of Maryland 構内 ; 構内の敷地は東京ドーム約 110 個分にあたり，広々とした緑の芝生のキャンパスに点 在する統一感のある潚酒な校舎の合間を市内バス，スクー ルバスが行き交っている。

私がお世話になったのは，近年，その優れた業績から その評価が大きく上昇し，2011 年の世界の工学・コン ピュータ部門大学ランキングでは 11 位になっている A James Clark School of Engineering の 8つの学科のうち, 1894 年に創設された Department of Civil and Environmental Engineering である。ここでは交通システムや水 資源，橋梁，インフラ，センサーなどの研究が行われ世 界的にも高い評価を得ている。

私の研修担当には, 副学部長の Alison B. Flatou 教授 とセンサーシステムが専門の Yunfeng Zhang 准教授が 当たってくださった。A. Flatou 教授には住まいの選定

* ひらいし・ひさひろ/明治大学理工学部建築学科 教授 (正会員)
など，Y.Zhang 准教授には研修面で多大なお世話を頂 いた。また元 NSF の C. Liu博士には公私にわたる支援 を受けた。大学の受け入れ態勢は極めてシステマ化され ている。研修中，日本から持ち寄った論文数編をまとめ 学会に投稿することができ，また研究面でも新たな構造 のヒントを得るなど私にとって極めて有意義な研修で あった。

\section{2011 Virginia Earthquake}

2011 年 8 月 23 日米東部ヴァージニア州リッチモンドの 北西約 $64 \mathrm{~km}$ のミネラル付近を震源とするマグニチュー ド 5.8 の地震が襲った。震源の深さはわずか $6 \mathrm{~km}$ で, 摇れは 20 秒から 30 秒続いた。米東海岸を襲った地震と しては, 1944 年のニューヨークーオンタリオ間で生じ たマグニチュード 5.8 の地震以来 68 年ぶりの米東部で の最大規模の地震であり, 震源から南西 $134 \mathrm{~km}$ の首都 ワシントン DC 中心部などが強い摇れに見舞われ，地震 後，連邦議会議事堂や国防総省，ニューヨークの高層ビ ル群などからの避難が一斉に始まった。

ワシントン DC 在住の日本人の話では震度 3 から 4 程 度の体感であったとのことである。

アメリカ東部は大西洋中央部やカリブ海の最も近いプ レート境界からでも数百 $\mathrm{km}$ 離れており，あまり地震が 起こらないが，地殼が硬い一枚岩の岩盤になっているた め，地震波が数百 $\mathrm{km}$ 遠くまで届くのが特徵である。今 回の地震はヴァージニア州の地域にある小さな断層に溜 まったひずみが解放されたごくまれな例だと考えられて いる。

この地震によりワシントン大聖堂や国会議事堂, 後述 のワシントンモニュメントなどの一部が損壊した。また 震源地から $13 \mathrm{~km}$ のところにあるノース・アナ原子力 発電所の原子炬 2 基が外部電源の閍失などの被害により 緊急停止されている。東日本大震災の原発事故の深刻な 影響下にいまだ曝されている我が国の現状を考えると事 態の深刻さに驚かされる。

なお 68 年程度の周期は, 東京を震度 6 強以上の地震 が襲う周期ともいえ，米東部での地震発生およびその規 模の目安となるような気がする。 


\section{Washington Monument と地震被害}

ワシントンモニュメントは 1848 年に建設が始まり， 一時中断の後 1884 年に完成している。大理石, 花崗岩, 砂岩よりなり，塔の高さは $169.294 \mathrm{~m}$, 土台幅は $16.8 \mathrm{~m}$, 記念塔土台幅は $16.8 \mathrm{~m}$, 土台部の壁の厚さは $4.6 \mathrm{~m}$, 頭頂部観覧階の壁の厚さは $46 \mathrm{~cm}$ である。世界で最も高 い石造であり，1889年に，パリのエッフェル塔が完成 されるまで，世界で最も高い建造物であった。

前述の地震後, 内部調査により塔のピラミッド状の冠 部に幅 $2.5 \mathrm{~cm}$, 長さ $12.5 \mathrm{~cm}$ の亀裂が確認された他, ブロック石の移動や石片，モルタルなどの飛散が確認さ れた。その後の外部からの調査などにより更なる亀裂や 下層部でのモルタルの脱落も確認された。構造的には安 全との調查報告がなされているが現在補修が進められ， 塔は無期限で閉鎖されている。補修に要する経費は約 15 億円掛かると見積もられている。
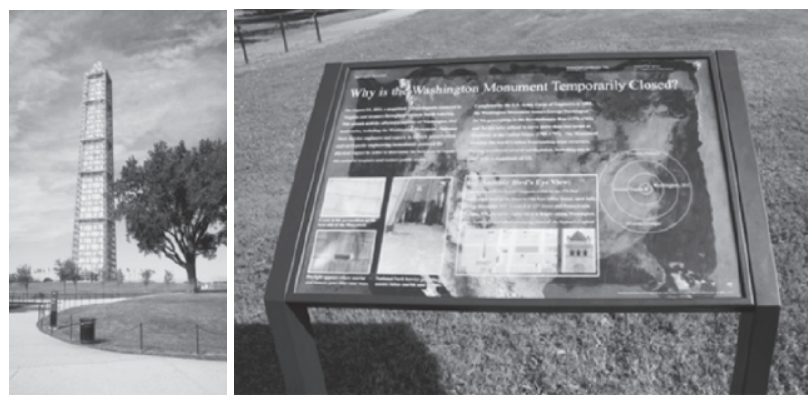

写真-2 補修中の Washington Monument と地震被害による閉鎖 を示す掲示板

\section{5. アメリカ留学事情}

久しぶりにアメリカに長期滞在し特に感じたことは, 韓国企業の活力と中華系人種の社会的進出であり，対し て日本の元気なさである。この活力の差は恐らく今後と も拡大し続けると思われ, 日本の国際的な競争力もさら に低下していくものと思われる。政府もその対策として ようやく学生の海外留学を支援するなどの政策を検討し 始めたようであるがことはそう簡単ではなさそうであ る。以下メリーランド大学での経験も踏まえアメリカの 留学事情について記す。

アメリカではファーマティブ・アクション（積極的差 別是正措置）の一環として大学入試に执いても，アフリ カ系やヒスパニック系などの進学率が低いことを是正す るため一定枠の確保が行われている。例えばアイビー。 リーグ大学の入学審査では大学進学適性試験（計 1600 点）の修正点は白人をゼロとするとアフリカ系は +230 点，ヒスパニック系 +185 点，アジア系 -50 点となって いる。その他，白人に有利な課外活動による優遇措置が あり，また学力レベルが低い高校でもその高校の上位 10\%は採用するなどアフリカ系に有利な措置を採用して
いる大学もある。

結果的にアメリカ留学を目指す日本人学生は十分な受 験対策を積みかつ語学力のある中国系, 韓国系の学生と アジア枠での競争を強いられる。語学力が世界でも最も 低い人種といわれかつ競争意識が近年低下している日本 人学生がこの関門を突破するのはますます困難になって いくものと思われる。

日本人留学生にとってもう一つの壁は日本人教員の少 なさであろう。私が滞在した学科でも，多くの中国系の 教員が存在し, 多数の中華系のアメリカ在住学生拈よび 留学生の指導を行っていた。日本人留学生を多く派遣す るためにも米国で活躍できる教員を早急に育成する必要 があるが，現在の日本の状況を考えると悲観的にならざ るを得ない。

\section{6.おわりに}

メリーランド大学は首都ワシントン DC に近くニュー ヨークを始めとする東海岸の情報にも接することができ た。また滞在中過ごしたべセスダの町は何とも魅力的で, 研究とともに生活面でも国内では得難い経験・知識を得 た。ただし改めて感じたのは我が国の国際競争力の低下 と将来への不安である。この現状を打破するため, 一人 でも多くの方が海外に目を向けて頂ければと切に願って いる。最後に在外研究の機会を与えて頂いた明治大学, 受け入れ先のメリーランド大学の関係者抢よびC. Liu 博 士に心より謝意を表します。

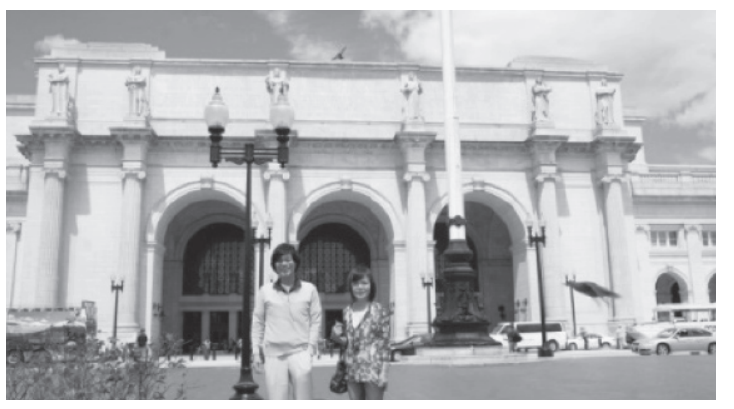

写真-3 Washington DC, Union Station ; Washington DC は政府 関連機関の施設が多いこともあり，市内には重厚な組積系 や鉄筋コンクリート系の建物が連なっている。

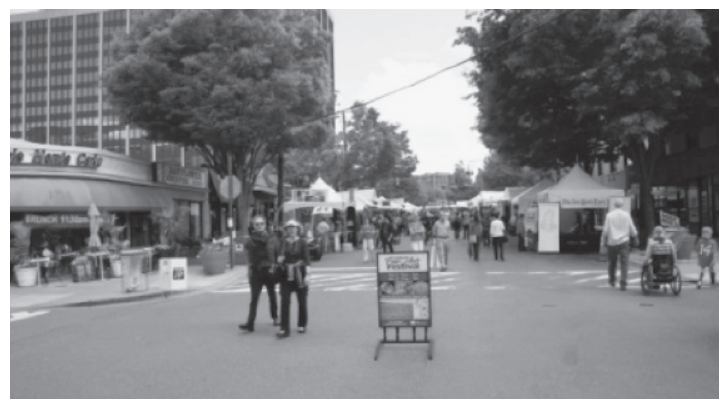

写真-4 筆者が過ごした Bethesdaでのアートフェスティバルで の風景；Bethesda は全米でも屈指の高学歴で高収入の人々 が住む Washington DC 郊外の高級住宅地として知られ，人 口 6 万の街に 200 店ものレストランが軒を連ねる。 